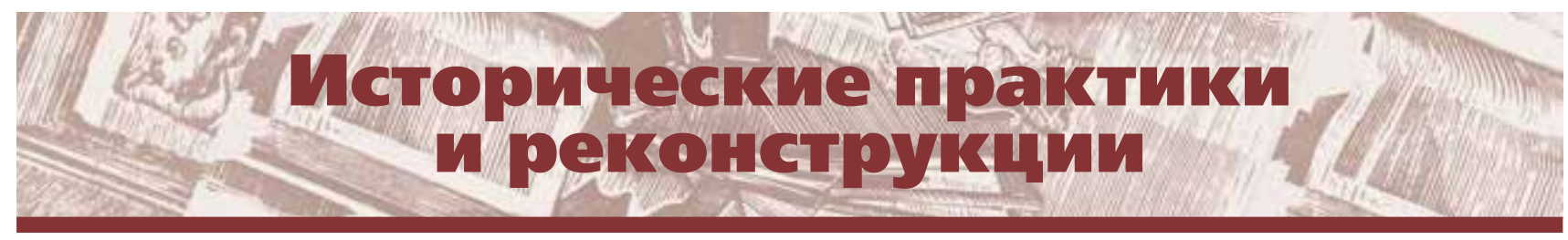

УДК 021.9(47)(91)

ББК 78.349.2г(2)53

DOI 10.25281/0869-608X-2018-67-1-91-101

Ю.В. Тимофеева

Источники финансирования

библиотек, учрежденных с помощью

Общества содействия устройству

сельских бесплатных библиотек-

читален в Томской губернии

(1901-1919 гг.)

Реферат. Статья продолжает серию публикаций в журнале «Библиотековедение», посвященных плодотворной деятельности Общества содействия устройству сельских бесплатных библиотек-читален в Томской губернии. Освещен важнейший вопрос источников финансирования, от решения которого зависели открытие, комплектование, деятельность библиотек, темпы библиотечного строительства и масштабы развития библиотечного дела. Выбранная тема достаточно актуальна, так как большой опыт по поиску источников финансирования, накопленный в дореволюционный период, способен быть полезным в настоящее время. Выявлены источники финансирования сельских библиотек в Томской губернии. Его составили частные капиталы и проценты с них (прежде всего самого П.И. Макушина - председателя Общества содействия, специально образованного им для устройства и поддержки бесплатных библиотек в Сибири), достигшие к 1912 г. 36 тыс. руб.; пожертвования известного издателя Ф.Ф. Павленкова, завещавшего значительную сумму на открытие народных библиотек, из которых 37 было устроено совместно с Обществом содействия в Томской губернии; отчисления в пользу Общества содействия столичных издателей и книготорговцев, составившие около 10 тыс. руб.; частные пожертвования, в том числе деятелей народного просвещения, местной интеллигенции, крестьян губернии; членские взносы, дававшие ежегодно от нескольких десятков до нескольких сотен рублей; ассигнования волостных и сельских сходов, губернского и уездных попечительств о народной трезвости, Министерства народного просвещения и др. Созданная П.И. Макушиным система финансирования позволила достичь серьезных успехов в деле библиотечного строительства в Томской губернии, выразившихся в открытии на ее территории менее чем за два десятка лет почти 600 бесплатных сельских библиотек.

Ключевые слова: история библиотек, народные библиотеки, Общество содействия устройству сельских бесплатных библиотек-читален в Томской губернии, Общество содействия, П.И. Макушин, источники финансирования, Ф.Ф. Павленков, частный капитал, издатели, книготорговцы, попечительства о народной трезвости.

Для цитирования: Тилофеева Ю.В. Источники финансирования библиотек, учрежденных с помощью Общества содействия устройству сельских бесплатных библиотек-читален в Томской губернии (19011919 гг.) // Библиотековедение. 2018. Т. 67, № 1. C. $91-101$. DOI: 10.25281/0869-608X-2018-67-191-101.

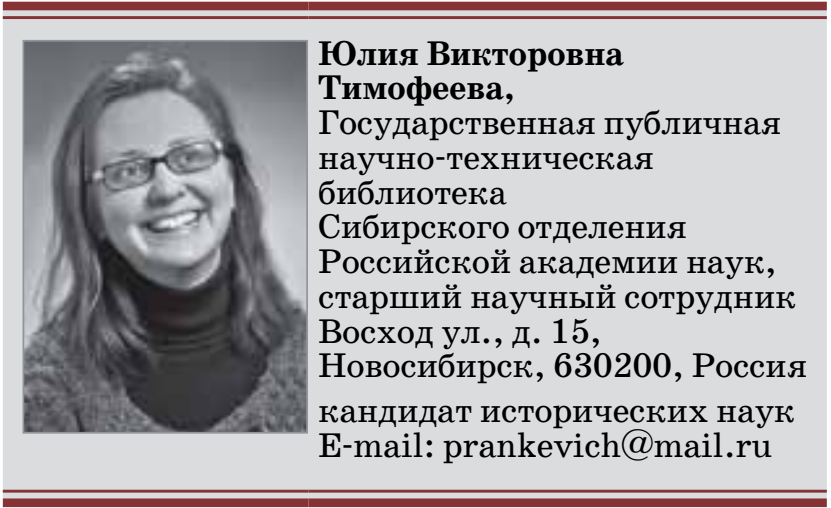


$\mathrm{B}$ ажным условием устройства и эффективной деятельности библиотек является их финансирование, от размеров которого зависят удобство помещения, количественный и качественный состав фонда и др. На это указывали, например, М.В. Курмаев [1] и А.М. Панченко [2; 3]. Основные источники финансирования деятельности Общества содействия устройству сельских бесплатных библиотек в Томской губернии (далее - Общество содействия) были перечислены еще на страницах дореволюционной профессиональной периодической печати [4, с. 275]. Позже они упоминались в работах советских и современных историков - М.Г. Прониной [5], Т.П. Карташовой [6], Ю.В. Тимофеевой [7; 8]. Но данный вопрос до сих пор так и не стал предметом самостоятельного исследования, отдельные источники в работах ученых лишь упоминались, иногда иллюстрировались отдельными фактами, обычно именами некоторых благотворителей, названиями учреждений и пожертвованными суммами. Однако изучение этой темы необходимо и важно. Во-первых, от источников и размеров финансирования напрямую зависят такие важнейшие показатели, как количество библиотек, названий, томов, экземпляров книг в них. Во-вторых, успешный опыт прошлого по поиску и привлечению к финансированию различных государственных учреждений, общественных организаций, частных фирм и лиц может быть востребован современными библиотеками и столетие спустя в целях привлечения ими средств для своей технической модернизации, современной организации пространства, полноценного комплектования фондов печатными и электронными изданиями, проведения культурно-массовых мероприятий по поддержке и продвижению чтения.

\section{Пожертвования I.M. Maкymura}

Крупнейшее пожертвование в пользу Общества содействия было сделано его организатором и бессменным председателем П.И. Макушиным, которым из собственных средств был образован специальный капитал [9; 10$]$.
По «Положению о капитале имени Петра Ивановича Макушина на устройство сельских бесплатных библиотек и читален в Сибири» П.И. Макушин образовывал его «для устройства и поддержания сельских бесплатных библиотек и читален в более населенных губерниях и областях Сибири, а именно в губерниях Томской, Тобольской, Енисейской и Иркутской и в областях Акмолинской и Семипалатинской» $[11$, с. 26$]$. Согласно воле пожертвователя первые 30 лет проценты с этого капитала должны были идти на устройство сельских библиотек исключительно в Томской губернии [11, с. 27]. Находился он, по просьбе самого П.И. Макушина, в заведовании и распоряжении Томского городского общественного управления.

Составлялся этот капитал «1) из единовременного пожертвования П.И. Макушина 5\% облигациями 3-го займа г. Томска по номинальной цене на 31200 руб.; 2) из последующих его же и его наследников посильных взносов тоже облигациями займов г. Томска; 3) из могущих быть остатков от ежегодных расходных сумм; 4) из ежегодных отчислений части получаемой с капитала процентов, пока основной капитал не достигнет до 1000000 руб.» [11, с. 26].

К августу 1910 г. капитал достиг в 5-процентных облигациях 33000 руб. и в наличных деньгах 14 руб. 29 коп. [11, с. 30].

На устройство библиотек ежегодно с 1909 г. по 1918 г. из суммы процентов с основного капитала планировалось расходовать по 750 руб. [11, с. 27], которые поступали, начиная с 1909 года. В результате за 1909-1912 гг. в кассу Общества содействия с капитала П.И. Макушина поступило 3000 руб., а сам капитал в 1912 г. определялся уже суммой в 36000 руб. [12, с. 9].

\section{Пожертвования Ф.Ф. Мавленкова}

Известный российский издатель Ф.Ф. Павленков завещал капитал на создание народных библиотек в России, которые должны были устраиваться при условии, что сумма, выделенная с процентов его капитала, дополнялась местным финансированием, в центральных губерниях страны 
Примеры комплектования сельских библиотек Томской губернии с привлечением средств, завещанных Ф.Ф. Павленковым [сост. по: 13]

\begin{tabular}{|c|c|c|c|}
\hline Населенный пункт & Уезд & $\begin{array}{c}\text { Число книг, полученных от } \\
\text { душеприказчиков } \\
\text { Ф.Ф. Павленкова }\end{array}$ & $\begin{array}{c}\text { Стоимость книг } \\
\text { (с учетом } \\
\text { переплета) }\end{array}$ \\
\hline с. Алтайское & Бийский & 225 & 56 руб. 05 коп. \\
\hline с. Борисовское & Кузнецкий & 245 & 57 руб. 57 коп. \\
\hline с. Верхне-Великосельское & Мариинский & 246 & 70 руб. 85 коп. \\
\hline с. Койновское & Барнаульский & 246 & 70 руб. 65 коп. \\
\hline с. Колпашево & Томский & 131 & 58 руб. 62 коп. \\
\hline с. Краснореченское & Мариинский & 246 & 70 руб. 91 коп. \\
\hline с. Красноярское & Змеиногорский & 246 & 70 руб. 43 коп. \\
\hline дер. Мало-Бащалакская & Бийский & 245 & 57 руб. 57 коп. \\
\hline с. Михайловское & Каинский & 246 & 71 руб. 09 коп. \\
\hline с. Овечинское & Каинский & 131 & 67 руб. 39 коп. \\
\hline с. Ординское & Барнаульский & 246 & 70 руб. 79 коп. \\
\hline с. Пестеревское & Кузнецкий & 131 & 67 руб. 42 коп. \\
\hline с. Покровское & Томский & 246 & 70 руб. 73 коп. \\
\hline с. Правдинское & Мариинский & 131 & 65 руб. 26 коп. \\
\hline с. Таскаевское & Каинский & 131 & 65 руб. 26 коп. \\
\hline с. Тихомировское & Томский & 131 & 58 руб. 62 коп. \\
\hline с. Тюменевское & Мариинский & 229 & 57 руб. 57 коп. \\
\hline с. Улалинское & Бийский & 246 & 59 руб. 63 коп. \\
\hline & Итого & 3698 & 1166 руб. 41 коп. \\
\hline
\end{tabular}

выделяемым земскими учреждениями. Однако в Сибири земства отсутствовали, и их роль в деле учреждения павленковских библиотек в Томской губернии взяло на себя Общество содействия.

Душеприказчики Ф.Ф. Павленкова В.Д. Черкасов, В.И. Яковенко и Н.А. Розенталь ежегодно, начиная с 1904 г., высылали значительное число книг для народных библиотек Томской губернии (табл. 1). Так, В.И. Яковенко на средства, завещанные покойным издателем на народные библиотеки в России, за период 1904-1907 гг. передал Обществу содействия «29 комплектов книг (5927 названий) стоимостью по номинальной цене на 1712 руб. 50 коп., не считая укупорку и пересылку, на которые затратили 91 руб. 62 коп.» [13, с. 6]. В 1908-1909 гг. душеприказчики Ф.Ф. Павленкова выслали для девяти библиотек 1269 книг на сумму 559 руб. 41 коп. [11, с. 3].

Благодаря щедрому завещанию известного книгоиздателя и ответственному исполнению его душеприказчиками своих обязанностей, в Томской губернии при участии Общества содействия с 1904 по 1910 г. было открыто 35 библиотек им. Ф.Ф. Павленкова: в Мариинском и Томском уездах - по 8, Каинском - 7, Барнаульском - 5, Кузнецком - 4, Бийском -2 , Змеиногорском - 1 (здесь и далее подсчеты произведены авторм статьи) [12, с. $29-$ $35]$.

В 1912 г. в Томской губернии насчитывалось уже 37 павленковских библиотек, книжное богатство которых оценивалось в 7867 руб. 40 коп., не считая стоимости пересылки и переплета книг [12, c. 10].

\section{Государственные ассигнования}

П.И. Макушин в своей просветительской деятельности сумел заручиться поддержкой государства [8, с. 106]. Общество содействия получало пособие из средств Министерства народного просвещения, выдававшихся по распоряжению попечителя Западно-Сибирского учебного округа Л.И. Лаврентьева. Оно составляло в 1910 г. 200 руб., в 1911 и 1912 гг. - по 300 руб. [4, c. 275$]$.

\section{Финансовая помощь попечительств - народной трезвости}

Многолетнее плодотворное сотрудничество велось Обществом содействия с губернским и уездными попечительствами о народной трезвости, оказавшими большую помощь в учреждении сельских библиотек.

Томское губернское попечительство о народной трезвости выдавало пособие Обществу по 500 руб. в 1904, 1905 гг. [13, с. 36], 1908, 1909 $[11$, с. 3$], 1910,1911,1912$ гг. [12, с. 6], что в сумме составило 3500 руб.

Томское уездное попечительство о народной трезвости ассигновало на приобретение книг для библиотек в своем уезде: в с. Богородском - 
77 руб. 42 коп. [14, с. 13], в с. Ишимском 76 руб. 59 коп. [13, с. 22], в с. Николаевском 81 руб. 79 коп. [13, с. 28$]$.

Наибольшую активность в устройстве сельских библиотек проявили Мариинский (председатель В.А. Пеньков) и Бийский (председатель В.П. Штейнфельд) уездные комитеты попечительства о народной трезвости. Первым было устроено 14 библиотек на сумму 1333 руб. 78 коп., вторым 7 библиотек на сумму 518 руб. 66 коп. [11, с. 3].

В результате на средства уездных попечительств о народной трезвости Обществом содействия в период с 1903 по 1912 г. было открыто 33 библиотеки, из них в Мариинском уезде - 18, Томском - 8, Бийском - 7 [12, с. $29-35 ; 15]$.

\section{Вклад столичных \\ (санкт-петербургских и московских) книгопродавцев и издателей в учреждение народных библиотек в томской губернии}

Значительный финансовый вклад в устройство бесплатных библиотек Томской губернии внесли столичные издатели и книгопродавцы. П.И. Макушин стал инициатором и организатором их участия в ассигновании средств на библиотечное строительство в далекой провинции, привлек их к этому благородному делу и нашел удобную форму отчисления денег в пользу Общества содействия.

Начало этой благотворительной акции, продолжавшейся несколько лет, было положено в 1910 г., когда П.И. Макушин, будучи в СанктПетербурге, перед собранием книгопродавцев сделал доклад об Обществе содействия, его задачах и результатах, достигнутых за восемь лет существования. В свое сообщение он включил просьбу: «Бессильный собственными и местными средствами удовлетворить указанную нужду, я, состоя в течение 36 лет членом почтенной семьи российских книгопродавцев, обращаюсь к товарищам по профессии с покорнейшею просьбою помочь мне в деле внедрения книги в забытой Сибири, не имеющей до сего времени земского самоуправления» $[16$, с. 2$]$.

Петр Иванович предложил форму возможной помощи этой особой категории предпринимателей, решающих своей деятельностью еще и просветительскую задачу: «Просимая мною помощь могла бы выразиться со стороны гг. книгопродавцев и издателей в таком виде и в такой форме: со всех платежей, какие будут следовать им за отпущенные ими для моего книжного магазина в г. Томске книги, дозволить мне удерживать в пользу Общества содействия устройству сельских бесплатных библиотек в Томской губернии - за книги собственных их изданий $5 \%$, с платежей за книги, находящиеся у них на складе, $-1 \%$ или хотя бы $1 / 2 \%$ » [16, с. 2].
Ответом на это сообщение стало постановление правления Русского общества книгопродавцев и издателей следующего содержания: «Оказать полное содействие к осуществлению просьбы П.И. Макушина о привлечении пожертвований на устройство библиотек-читален путем напечатания в “Книжном Вестнике” настоящего его сообщения и открытия в журнале особого отдела для помещения в нем фирм и лиц, кои пожелают откликнуться на призыв П.И. и со своей стороны всячески пропагандировать идею г. Макушина» $[16$, с. 3]. Такое же постановление было принято и правлением Московского общества книгопродавцев и издателей. Согласие на отчисление в пользу Общества содействия 5\% с платежей, которые будут следовать от П.И. Макушина на купленные им книги их собственного издания, к 1 августа 1910 г. дали 30 петербургских, 14 московских и 2 провинциальных (киевский и нижегородский) издателя и книгопродавца, всего 46 человек [11, c. $20-21]$.

В разговоре с П.И. Макушиным известный российский издатель А.С. Суворин выразил горячее сочувствие его начинанию и высказался о том, что «свой отказ в предложенном содействии распространению книги в народе он считал бы преступлением против родины» [12, с. 7].

В результате с 1910 г. Обществу содействия стала оказываться ценная поддержка со стороны почти всех крупных издателей, имеющих торговые отношения с томским книжным магазином П.И. Макушина (табл. 2).

таблица 2

Финансовая помощь книгоиздателей

и книгопродавцев Обществу содействия в 1910-1915 гг. [сост. по: 16, с. 3]

\begin{tabular}{|c|c|}
\hline Годы & Сумма \\
\hline 1910 & 920 руб. 94 коп. \\
\hline 1911 & 1784 руб. 63 коп. \\
\hline 1912 & 1422 руб. 09 коп. \\
\hline 1913 & 1618 руб. 79 коп. \\
\hline 1914 & 1747 руб. 93 коп. \\
\hline 1915 & 1841 руб. 90 коп. \\
\hline Итого & 9336 руб. 28 коп. \\
\hline
\end{tabular}

В 1915 г. список лиц и фирм, откликнувшихся на предложение П.И. Макушина и делавших процентные отчисления в пользу народных библиотек в Томской губернии, включал 49 фамилий и названий фирм. Самая большая сумма за период с 1910 по 1915 г. поступила от «Товарищества И.Д. Сытина и К $^{\circ}-2201$ руб. 82 коп., значительно опередив "Практическую медицину" Ф.В. Эттингера - 800 руб. 56 коп. и Д.И. Тихомирова - 479 руб. 13 коп., расположившихся на втором и третьем местах соответственно [16, c. 5-7].

Наименьшее пожертвование - в сумме 37 коп. - поступило от редакции журнала 


\section{списокъ}

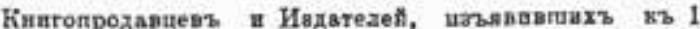
aвr. $1910 \mathrm{r}$. свое coraacie na orqueaenie въ nozbay 06-

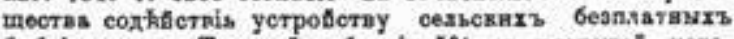

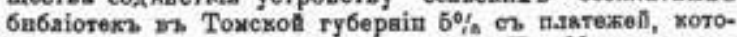

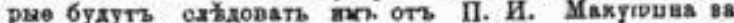

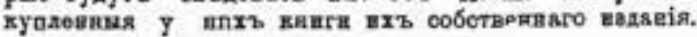

\section{IIemepöypnexie кNunonpodaerys:}

Авасимовъ Bacuain Петровачz.

Баздовъ Каке Ивановиซz.

Bporraysz-Eфровз".

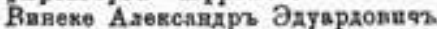

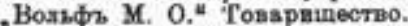

Гoabcreaz Гeoprín Baceabean

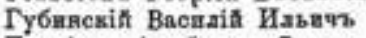

Девріенъ Атьфрехь Федоровачъ. К-ио

Лостоевекаs Aнss Tprropbess

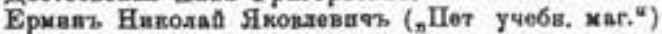

3asaie? T so.

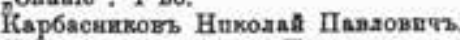

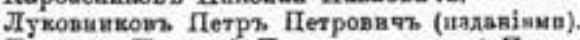

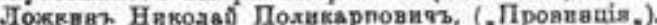

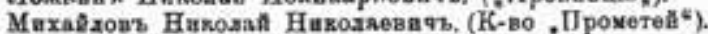

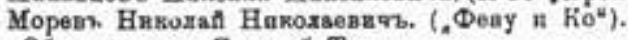

„Общественвая Полиав" T-во.

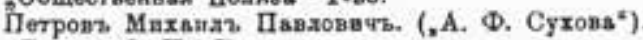

„Пlonoss O. H.* K-no.

Пlocłera". K-po.

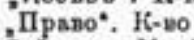

Cafanosa Mapia Hnxoareans.

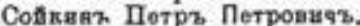

Craconsenayz. Maxagazb Marbłeвzrz,

Cronerana Mapis Накольевав, $(10 \%)$.

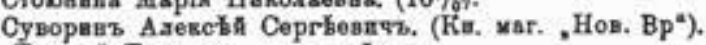

Трукз" Т-во вея. п над,-дала.

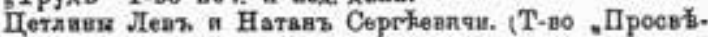
mथाiอ*).

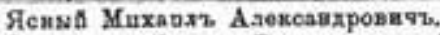

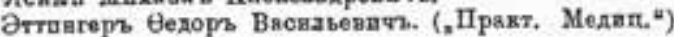

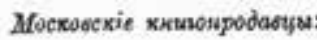

Byouraab Фaannm Bacnabeaqu.

Горбувовъ Ияавъ Квавовачъ. („Пооредвивъ")

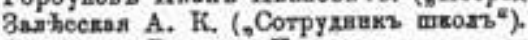

Запетрекъ Вакторз Петровать.

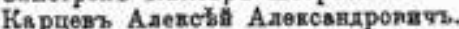

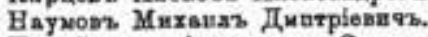

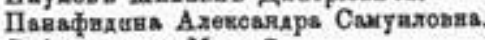

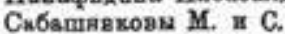

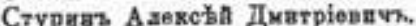

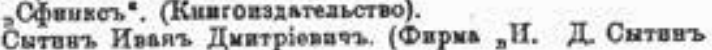

u $\left.\mathrm{K}_{0} \mathrm{u}\right)$.

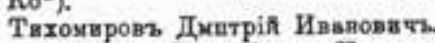

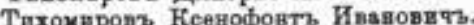

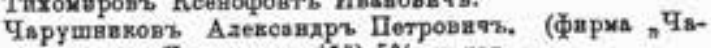

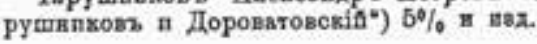

\section{I poruntyiasssme кNtusospodoerys:}

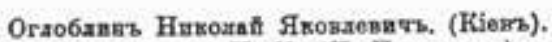

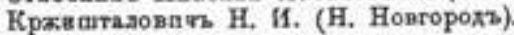

Список издателей и книгопродавцев, отчислявших

Обшеству содействия $5 \%$ с платежей П.И. Макуши на на изданные или книги [11, с. 20-21]

«Физик-любитель». Однако и оно было важно. П.И. Макушин в уже упоминавшемся выше выступлении перед книгопродавцами и издателями уверял их: «Все пожертвования, в какой бы сумме они ни выразились, будут приняты Обществом [содействия] с глубокою благодарностью...» [16, с. 2].

Кроме этого, А.С. Панафидиной, по случаю 25-летнего юбилея ее издательской деятельности, было пожертвовано на открытие 20 библиотек 1000 руб. [16, с. 3].

Финансовое участие книгопродавцев и издателей в деле устройства народных библиотек в Томской губернии заметно способствовало их росту. В 1910 г. Обществом содействия было открыто 65 библиотек, в 1911 г. - 58, в 1912 г. - 64, в 1913 г. - 59, $1914-51,1915$ г. - 54 библиотеки, всего за шесть лет - 351 библиотека [16, c. 4], в то время как за предыдущие восемь лет (с 1902 по 1909 г.) - 96 библиотек (в среднем 12 библиотек в год) [12, с. 29-35].

\section{Финансовое участие сельских жителей в устройстве библиотек}

На сельских сходах не только обсуждался вопрос о необходимости открытия бесплатной библиотеки в своем селе, но и при его положительном решении рассматривались возможности ее финансирования из местных средств. Например, на устройство двух первых народных библиотек, устраиваемых с помощью Общества содействия в селах Судженском и Ново-Кусковском Томского уезда в 1902 г. [17], местными волостными сходами было ассигновано 200 руб. и 60 руб. соответственно [14, с. 7,8$]$. Кроме того, Ново-Кусковское сельское общество за четыре первых месяца 1903 г. дважды выделяло средства (58 руб. 52 коп. и 95 руб. 70 коп.) на пополнение своей библиотеки, благодаря чему количество книг в ней увеличилось на 303 экземпляра $[14$, c. 8$]$.

Сельский сход пос. Островского Мариинского уезда своим решением единовременно ассигновал на нее 10 руб. и пообещал ежегодно давать по 1 коп. с души мужского пола, благодаря чему в 1903 г. было собрано 2 руб. 81 коп., на которые приобрели 15 книг [14, с. 10].

Волостными сходами было ассигновано на открытие библиотек в с. Семилужном Томского уезда 200 руб., в с. Смоленском Бийского уезда 100 руб. [14, с. $12-13]$.

Из мирского капитала волостными правлениями были выделены средства на устройство библиотек в с. Бугры [13, с. 18] и с. Гутовском Томского уезда [13, с. 20].

Год от года увеличивалось число селений, которые желали устроить у себя библиотеку. При этом крестьяне начали делать посильные вложения из личных средств. Так, за 1908-1909 гг. в 15 селениях таких пожертвований было сделано на сумму 455 руб. 84 коп. [11, с. 3-4].

По подписке среди местных жителей были собраны деньги на открытие библиотеки с. Зюзинского Каинского уезда [13, с. 21].

Библиотека в с. Сорокинском Барнаульского уезда была открыта на средства попечителя школы купца Макарова, который единовременно 


\section{Cписокъ}

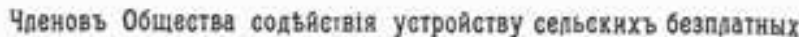
6нбаіотекъ-читаленъ вь Томской губервія.

\section{Почетние чиена:}

Высокопреосвященный Макарій, Митрополитъ Мс сковскій и Коломенскій. Гранъ.

Томскій Губернаторъ д. ст. с. Петръ Карлович

Попечитель Западно-Сибнрскаго учебнаго округ т. с. Леонидъ Ивановичъ Лаврентьевъ.

Британское и Иностранное Библейское Общество.

Вольфъ Людвигъ Маврикіевичъ.

Горбуновъ Иванъ Ивановичъ.

Кнебель Іосифъ Николаевичъ.

Девріенъ Альфредъ Федоровичъ.

Макушинъ Петръ Ківановичъ.

Поповъ Петръ Ивановичъ.

Ступинъ Алексьй Дмитріевичъ.

Суворинъ Алексьй Сергьевичъ,

Смтинъ Иванъ Дмитріевичъ.

Тихоміровъ Дмитрій Ивановичъ.

Товарищество ,Просвьщеніе“.

\section{Пожизненные члемь:}

Князь Сергй Александровичз Вяземскій.

Горохова Анна Ивановна.

- Гороховъ Владимиръ Александровичъ.

Ложниковъ Петръ Ивановичъ.

Попова Матильда Андреевна.

* Попова Надежда Петровна.

Попова Ольга Петровна

Поповъ Андрей Петровичъ.

\section{Список почетных и пожизненных членов} Общества содействия [12, с. 36-37]

пожертвовал на нее 150 руб. [14, с. 9]. Учителем Усольцевского сельского училища Юдинской волости Каинского уезда было собрано добровольных пожертвований на библиотеку 6 руб. 21 коп. $[14$, c. 11$]$.

Крестьянин В.Д. Ложкин устроил в родном с. Итатском народную библиотеку на деньги, которые следовали ему в качестве вознаграждения за заведывание волостным сельским банком в размере 100 руб. [13, с. 20].

В с. Кауракском местный житель Ф.П. Пятков безвозмездно передал в библиотеку своего села собственное собрание, состоявшее из 100 книг. В с. Усть-Чарышском Н.И. Ступаков предоставил во временное пользование жителей села свою библиотеку в 350 книг [11, с. 3-4].

По инициативе представителей местной интеллигенции и на собранные ими средства были открыты библиотеки: в с. Кыштовском Каинского уезда - благодаря активности инородца Д.С. Сибирцева и мещанина Н.Л. Севастьянова, собравшими от частного кружка 150 руб. [14, c. 13]; в с. Алтайском Бийского уезда - усилиями М.Ф. Морозова, Петрова, К.К. Трусова, И.Н. Репина, А.П. Фирсова, А.Т. Головина, Н.Н. Семина, Е.В. Щербакова и священника о. А. Рыбкина, собравшими 70 руб. 30 коп., на ко-

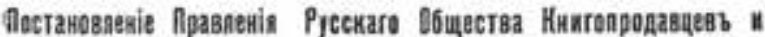
Нздателей, состенвшееси 2 шеврала $1910 \mathrm{r}$.

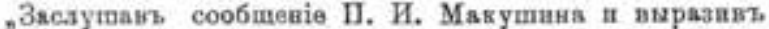
II. И. за ато coобщевіе своко таубокую благоарвость, Шравленіе от всей души привьтотвовало Петра Ивановнча за его великую и безкоркотаую дызтельвость на польау куаьтурнаго разватія дахекой Сибари и заявиао,

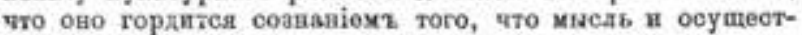

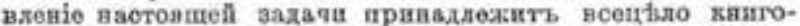
продавцу-вздатеаю, члев у Русокаго Oбпества Kuйородавдевъ и Иадатедељ, и постаяовша: оказать поаное свое

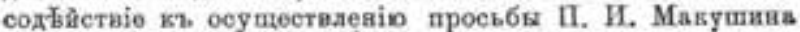

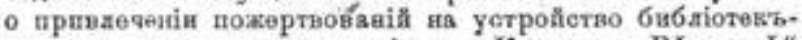

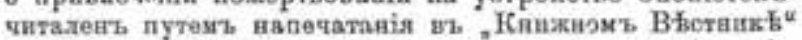
настоящаго его сообтевіл и открктія въ хурналь особа-

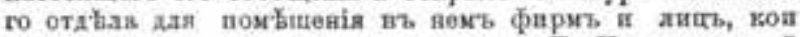

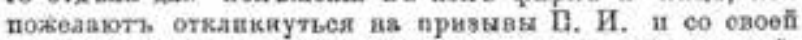
еторовн всаческо пропагандироһать вдею г. Макушина".

$$
\text { (,Kwиark. Brem." } 1910 \text { 2. K 7). }
$$

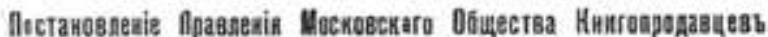 и. Нздатепей, состонвшеесн 20 янв, $1910 \mathrm{r}$.}

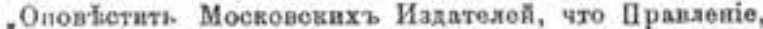

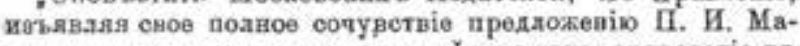
вушнав, полагаоть возмоякикъъ дүлать такое отчвслевіе въ

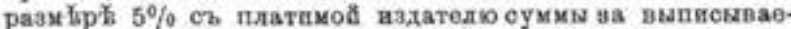

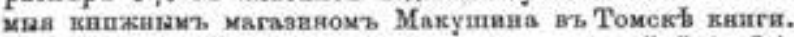

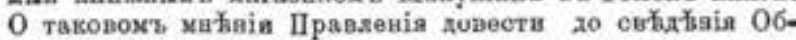
maro Coбpasis*.

(Kruжен. Bucms. 1910 s. N: 6

Постановления правления Русского общества книгопродавцев и издателей и правления Московского общества книгопродавиев и издателей [11, с. 19]

торые было приобретено 208 книг, в дальнейшим ими же накапливались средства на пополнение библиотеки [13, с. 16]; в дер. Мало-Бащалакской - Д.В. Нарожного, Н.М. Пастухова, И.Ф. Брусянина, А.Д. Ошлакова, Ф.В. Москвина, собравшими 40 руб. [13, с. 27]; в с. Уртамском - В.С. Войшвилло, А.О. Гичевского, Ф.А. Кириллова, О.Ф. Стадникова и И.П. Суворова, собравшими 169 книг (наиболее ценные поступили от В.М. Наумова и Н.Н. Ворожцова) и 64 руб. 40 коп., на которые было приобретено 216 номеров разных книг [11, с. 4].

Местные жители жертвовали непосредственно в библиотеки своих селений книги, журналы и приложения к ним. Наиболее ценные пожертвования книгами были сделаны в Усть-Чарышскую библиотеку Е.Н. Пономаревым на 270 руб., 54 книги в Барлакскую библиотеку - Пермяковым, 20 в Боровскую - Мерс, 144 в Крутихинскую - С.Г. Лаптевым, от разных лиц 100 книг в Лянинскую, 53 - в Лотошную и еще в 40 библиотек от 1 до 40 книг [12, с. 28].

Суммы, выделяемые крестьянами на книги для народной библиотеки, ежегодно росли. Если на покупку книг за 1910-1912 гг. было собрано местных средств 2024 руб. 41 коп. [12, с. 20], то за последующие три года (в 1913-1915 гг.) 6099 руб. 76 коп. [6, с. 214]. 
Категории и общее число членов Общества содействия [сост. по: 11 , с. $1 ; 12$, с. $16 ; 13$, с. $1 ; 14$, с. $23-27$ ]

\begin{tabular}{|l|c|c|c|c|c|c|}
\hline \multicolumn{1}{|c|}{ Категории членства } & $1901-1903$ гг. & $1904-1907$ гг. & 1908-1909 гг. & 1910 г. & 1911 г. & 1912 г. \\
\hline Почетные члены & 3 & 3 & 3 & 3 & 3 & 3 \\
\hline Пожизненные члены & 5 & 5 & 10 & 10 & 10 & 10 \\
\hline Действительные члены & 127 & 42 & 59 & 24 & 23 & 42 \\
\hline Итого & 135 & 50 & 72 & 37 & 36 & 55 \\
\hline
\end{tabular}

\section{Частные пожертвования}

Не только местные жители жертвовали деньги на устройство книжных собраний в своих селениях, но и горожане помогали открывать сельские библиотеки. В каждом отчете Общества содействия отмечались «факты сочувствия и содействия в устройстве сельских библиотек в пределах Томской губернии». Например, студенты Костромского землячества при Императорском томском университете на общем собрании постановили отчислять от ежемесячного членского взноса $4 \%$ в пользу Общества содействия [13, с. 7]. Так, в 1910 г. от них было получено 70 коп. [12, c. 27].

Известным просветителем В.П. Вахтеровым было передано в кассу Общества содействия 1200 руб. на библиотеки его имени [16, с. 3].

От разных лиц было пожертвовано за $1901-$ 1903 гг. 145 руб. 95 коп. [14, с. 28], за 19081909 гг. 156 руб. 26 коп. [11, с. 14].

В 1910 г. почетный лектор В.А. Поссе передал в кассу Общества содействия сбор с одной из своих лекций, прочитанных им в Томске, в сумме 194 руб. [12, с. 6].

\section{Членские взносы}

Согласно Уставу Общества содействия его члены разделялись на: действительных, пожизненных, почетных и ревнителей. Сам Петр Иванович являлся пожизненным членом, а его младший брат Алексей Иванович Макушин и дочь Елизавета Петровна Макушина - действительными членами Общества содействия.

Первое значительное пожертвование в 500 руб. поступило при открытии Общества содействия в 1901 г. от инициатора его создания П.И. Макушина. В том же году пожизненными членами стали А.И. Горохова, В.А. Горохов, П.И. Ложников, внесшие по 50 руб. $К$ ним присоединились, сделав пожизненный взнос в 50 руб., в 1903 г. кн. С.А. Вяземский, в 1908 г. - американские граждане М.А. Попова, П.И. Попов, Н.П. Попова, О.П. Попова, А.П. Попов [12, с. 6].

Численность Общества содействия ежегодно изменялась, и эта динамика далеко не всегда имела положительный характер (табл. 3). Наибольшая численность была зафиксирована в год создания этого общества. В последующие годы наблюдалась ярко выраженная тенденция со- кращения числа участников. Количественные изменения численности действительных членов Общества содействия отражены в сведениях табл. 4.

Таблица 4

Число действительных членов Общества содействия, плативших взносы в размере 3 руб. в 1901-1912 гг. [12, с. 5].

\begin{tabular}{|c|c|}
\hline Годы & $\begin{array}{c}\text { Число действительных членов } \\
\text { Общества содействия }\end{array}$ \\
\hline 1901 & 108 \\
\hline 1902 & 50 \\
\hline 1903 & 40 \\
\hline 1904 & 26 \\
\hline 1905 & 15 \\
\hline 1906 & 10 \\
\hline 1907 & 21 \\
\hline 1908 & 43 \\
\hline 1909 & 23 \\
\hline 1910 & 24 \\
\hline 1911 & 23 \\
\hline 1912 & 42 \\
\hline
\end{tabular}

Членские взносы поступали в кассу Общества содействия, способствуя устройству бесплатных библиотек в селениях губернии (табл. 5).

\section{Пожертвования печатными изданиями}

Пожертвования в пользу Общества содействия поступали не только деньгами, но и печатными изданиями: книгами, брошюрами, журналами.

В распоряжение Совета Общества содействия «поступило от В.И. Дуровой книжек разных перио-

Таблииа 5

Сумма поступлений в кассу Общества содействия от уплаты членских взносов в 1901-1912 гг. [сост. по: 11 , с. $9 ; 12$, с. $22 ; 13$, с. $36 ; 14$, с. 15]

\begin{tabular}{|c|c|}
\hline Годы & Сумма \\
\hline $1901-1903$ & 735 руб. \\
\hline $1904-1907$ & 208 руб. \\
\hline $1908-1909$ & 444 руб. \\
\hline 1910 & 49 руб. \\
\hline 1911 & 34 руб. \\
\hline 1912 & 174 руб. \\
\hline Итого & 1644 руб. \\
\hline
\end{tabular}




\section{КАССОВЫЙ ОТИЕТЬ}

Совьта О-за сод. устройству сельск. б-къ въ Томск. губ. за 1910-1912 годы (по 10 дек.).

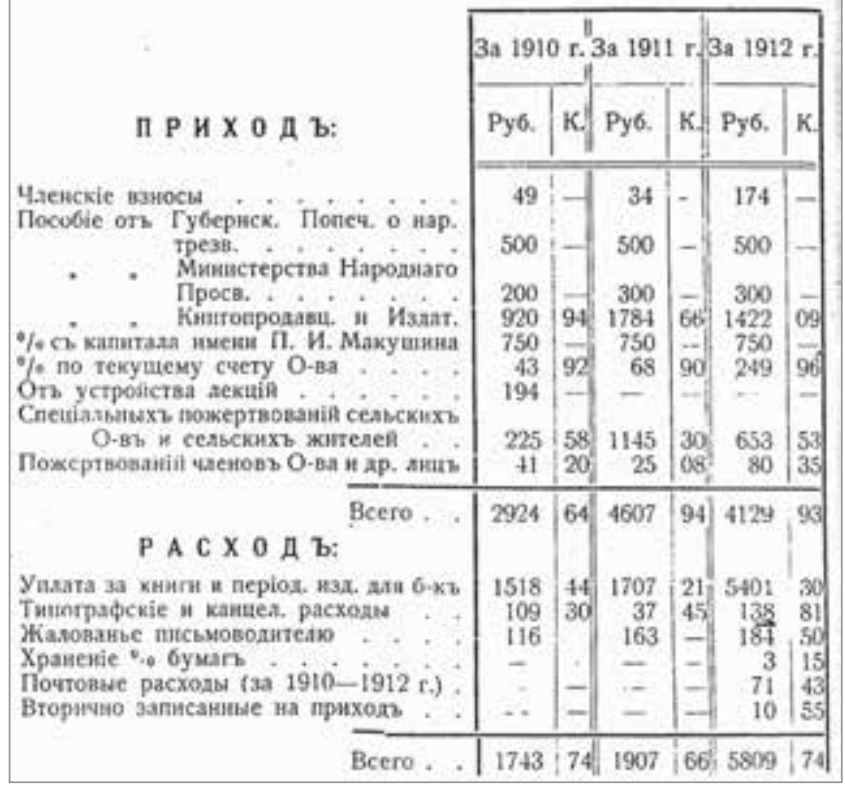

Кассовый отчет Общества содействия за 1910-1912 г2. [12, c.22]

дических изданий за минувшие годы 218 номеров, от неизвестного мелких брошюр и книжек для народа 99, от Л.А. Орловой 1 книга, от неизвестных 13 книг, от неизвестных 1 книга» [14, с. 16].

Также поступили пожертвования книгами на сумму свыше 10000 руб. от Н.Я. Ермина, В.И. Губинского, П.П. Луковникова, А.И. Чарушникова, М.С. Ломшакова, М. и С. Сабашниковых, британского Библейского общества и др. [16, с. 4].

Агент британского Библейского общества, распространявший Священное Писание по Сибири, В.В. Девидзон испросил у Совета этого общества (в Лондоне) дозволение в каждую из уже открытых и устраиваемых в дальнейшем при помощи Общества содействия библиотек пожертвовать по экземпляру Библии и Нового Завета на русском языке, что стало весьма ценным подарком [13, с. 6]. В последующие годы британское Библейское общество продолжало жертвовать Библию и Новый Завет на русском языке в каждую из открываемых Обществом содействия библиотек [11, с. 3$]$.

Поступило изданиями от Н.Я. Еремина на 86 руб., от редакции журнала «Жизнь для всех» на 210 руб., Дороватовского и Чарушникова на 65 руб. 50 коп., В.П. Луковникова на 42 руб., редакции «Вятской речи» на 120 руб., Б.Э. Кетриц на 14 руб. 77 коп., В.Я. Протопопова на 200 руб. [12, с. 26].

Книги и журналы жертвовали Обществу содействия не только издатели, редакции периодических изданий и другие создатели печатной продукции, но и частные лица, род занятий которых находился вне издательской деятельности (табл. 6).
Таблица 6

Количество книг, пожертвованных в пользу Общества содействия частными лицами в 1901-1912 гг. [сост. по: 11 , с. $14 ; 12$, c. $28 ; 13$, с. $37 ; 14$, c. 16$]$

\begin{tabular}{c|c}
\hline Отчетный период & Кол-во книг \\
\hline $1901-1903$ гг. & 332 \\
\hline $1904-1907$ гг. & $916^{*}$ \\
\hline $1908-1909$ гг. & $317^{* *}$ \\
\hline $1910-1912$ гг. & $1145^{\text {** }}$ \\
\hline Итого & 2710 \\
\hline
\end{tabular}

* Кроме того, за этот период были пожертвованы литературные приложения к «Ниве» за 1905 год.

** Кроме того, за этот период были пожертвованы периодические издания, в том числе «Родная речь» за 1904 и 1905 гг., «Нива» за 1899-1908 гг. и др.

*** Кроме того, за этот период были пожертвованы периодические издания, в том числе журналы «Вестник знания» за 1911 г. № $1-12$ и «Спутник средней школы» за 1909 г. № $1-24$.

\section{Финансовые средства церковных попечительст:}

Соответствующими церковными попечительствами было дано на устройство библиотек в с. Жћуланихинском и в с. Парфеновском Барнаульского уезда 20 руб. и 10 руб. соответственно [13, с. 21,30$]$.

\section{Выводы}

Данные табл. 7 демонстрируют денежные суммы, поступившие в кассу Общества содействия из всех источников.

Таблица 7

Итоговые суммы поступления денежных средств из всех источников в Общество содействия

[сост. по: 11 , с. $9 ; 12$, с. $22 ; 13$, с. $36 ; 14$, с. 15]

\begin{tabular}{|c|c|}
\hline Годы & Сумма \\
\hline 1901 & 1137 руб. 66 коп. \\
\hline 1902 & 223 руб. 17 коп. \\
\hline 1903 & 546 руб. 16 коп. \\
\hline 1904 & 1127 руб.03 коп. \\
\hline 1905 & 724 руб. 15 коп. \\
\hline 1906 & 51 руб. \\
\hline 1907 & 42 руб. \\
\hline 1908 & 1121 руб. 73 коп. \\
\hline 1909 & 1746 руб. 26 коп. \\
\hline 1910 & 2924 руб. 64 коп. \\
\hline 1911 & 4607 руб. 94 коп. \\
\hline 1912 г. (по 10 дек.) & 4016 руб. 93 коп. \\
\hline Итого & 18268 руб. 67 коп. \\
\hline
\end{tabular}

Таким образом, П.И. Макушин сумел привлечь к устройству и обеспечению работы народных библиотек частный капитал, государственные 
субсидии, средства общественных организаций и личные сбережения людей, а также бесплатный труд, чаще всего учителей, соглашавшихся безвозмездно исполнять обязанности заведующих. Финансовая система, созданная П.И. Макушиным и основанная на его огромном организаторском таланте, большом личном денежном вкладе, широком круге источников финансирования, привлечении государственных ассигнований и средств столичных деятелей просвещения, издания и книжной торговли, позволила достичь небывалых успехов в открытии народных библиотек в Томской губернии, в которой в период с 1902 по 1919 г. усилиями Общества содействия и его организатора и бессменного председателя П.И. Макушина было учреждено около 600 культурно-просветительских учреждений с общим фондом примерно в 300 тыс. книг и общим числом пользователей свыше 50 тыс. человек [18, с. 41].

\section{Список источников}

1. Курлаев М.В. Книжная культура Среднего Поволжья конца XVIII - начала XX в. (на материалах Пензенской, Симбирской и Самарской губерний): автореф. дис. ... д-ра ист. наук. Самара, 2010. 50 с.

2. Панченко A.M. История военных библиотек в контексте развития библиотечного дела России (1802-1917 гг.): автореф. дис. ... д-ра ист. наук. Новосибирск, 2017. 57 с.

3. Панченко А.М. Финансирование офицерских библиотек русской армии во второй половине XIX начале XX в. // В Сибири рожденное : к 40-летию Новосибирского высшего военного командного училища (1967-2007) : материалы науч. конф. (Новосибирск, 27 апреля. 2007 г.). Новосибирск, 2007. C. $115-126$.

4. Хроника // Библиотекарь. 1912. Вып. III-IV. C. $261-277$.

5. Пронина М.Г. Общество содействия устройству сельских бесплатных библиотек-читален в Томской губ. // Книжное дело Сибири и Дальнего Востока в XIX-XX вв. Новосибирск : ГПНТБ СО РАН, 1986. C. $39-50$.

6. Карташова Т.П. Макушинские библиотеки и продвижение местной печатной продукции в Томской губернии в начале XX в. // Книга: Сибирь - Евразия : тр. I Междунар. науч. конгр. : в 3 т. / Гос. публ. науч.-техн. б-ка Сиб. отд-ния Рос. акад. наук. Новосибирск : ГПНТБ СО РАН, 2016. Т. 2. С. 211-219.

7. Тимофеева Ю.В. Книжная культура сельского населения Западной Сибири (конец XIX - начало XX в.) : монография. Новосибирск : Центр развития науч. сотрудничества, $2012.193 \mathrm{c.}$

8. Тилофеева Ю.В. О чем рассказал отчет, или Потенциальные возможности одного документа // История и историография России и Сибири в исследовательском и образовательном контекстах : материалы Всерос. науч.-практ. конф. (Новосибирск, 15-16 апреля 2014 г.). Новосибирск : Новосиб. гос. пед. ун-т, 2014. С. 103-108.

9. Меньщикова С.П. У истоков народного просвещения в Сибири // Вестник Библиотечной Ассамблеи Евразии. 2015. № 3. С. 85-87.

10. Тимофеева Ю.В. Петр Иванович Макушин и устройство народных библиотек в Томской губернии в начале XX века // Вестник Библиотечной Ассамблеи Евразии. 2015. № 3. С. 88-91.

11. Отчет Совета Общества содействия устройству сельских бесплатных библиотек-читален в Томской губернии за 1908-1909 гг. Томск : Типо-литография Сибирского товарищества печатного дела, 1910.30 с.

12. Краткий очерк возникновения и деятельности Общества [содействия устройству сельских бесплатных библиотек-читален в Томской губ.] за время его существования и отчет Совета Общества за 1910-1912 гг. Томск : Тип. Дома трудолюбия, 1912.45 с.

13. Отчет Совета Общества содействия устройству сельских бесплатных библиотек-читален в Томской губернии за 1904-1907 гг. Томск : Типо-литография Сибирского товарищества печатного дела, 1908.49 с.

14. Отчет Совета Общества содействия устройству сельских бесплатных библиотек-читален в Томской губернии за 1901-1903 гг. Томск : Паровая типолитография П.И. Макушина, 1904. 30 с.

15. Тилофеева Ю.В. Библиотеки Общества содействия устройству сельских бесплатных библиотек-читален в Томской губернии (1901-1919 гг.) // Библиотековедение. 2017. Т. 66, № 4. С. 443-450. DOI: 10.25281/0869-608X-2017-66-4-443-450.

16. Участие книгопродавцев и издателей в учреждении народных библиотек-читален в Томской губернии. [Томск : Типо-литография Сиб. товарищества печатн. дела, 1916 ?]. $7 \mathrm{c.}$

17. Тимофеева Ю.В. Две первые библиотеки Общества содействия устройству сельских бесплатных библиотек-читален в Томской губернии (первое десятилетие XX в.) // Библиотековедение. 2017. T. 66 , № 2. C. 202-208. DOI: 10.25281/0869-608X2017-66-2-202-208.

18. Макушин П.И. Из «Автобиографии» // Сибирская старина. 2002. № 19. С. 35-41.

Иллюстративный материал предоставлен авторол статьи 


\title{
Sources of Financing the Libraries established with the assistance of the Society for Promotion of Rural Free Libraries-Reading Rooms in the Tomsk Province (1901 - 1919)
}

Yulija V. Timofeeva,

State Public Scientific and Technological Library of the Siberian Branch of the Russian Academy of Sciences, 15 Voskhod Str., Novosibirsk, 630200, Russia

E-mail: prankevich@mail.ru

\begin{abstract}
The article continues a series of author's publications in the "Bibliotekovedenie" [Library and Information Science] journal, devoted to the fruitful activity of the Society for Promotion of Rural Free LibrariesReading Rooms in the Tomsk Province. There is illuminated the vital question of the sources of financing, on the solution of which depended opening, acquisition, activity of libraries, the rate of progress of library construction and scale of development of librarianship. The chosen theme is quite relevant, because the wide experience in searching for the sources of financing, accumulated in the pre-revolutionary period, could be useful nowadays. Sources of financing for the rural libraries in the Tomsk province are identified. It was composed by: private capital and the interest on it (firstly, of P.I. Makushin - Chairman of the Society for promotion, specially established by him for the assistance and support of free libraries in Siberia), reached by 1912 the amount of 36 thousand roubles; the donations of F.F. Pavlenkov, well-known publisher, bequeathed the considerable amount to the opening of peoples libraries, 37 of which were founded jointly with the Society for promotion of rural free libraries-reading rooms in the Tomsk province; contributions to the advantage of the Society of assistance of metropolitan publishers and book sellers, estimated at around 10 thousand roubles; private donations, in particular, of the leaders of national education, local intelligentsia, and peasants of the province; the membership dues, making annually from several tens to several hundred roubles; fund allocations of the volost and village assemblies, provincial and district trusteeships on people's sobriety, the Ministry of national education, etc.

The system of financing created by P.I. Makushin has allowed achieving serious success in library construction in the Tomsk province, implemented in the opening in its territory in less than two decades of nearly 600 free rural libraries.
\end{abstract}

Key words: History of Libraries, National Libraries, Society for Promotion of Rural Free Libraries-Reading Rooms in the Tomsk Province, Society of Assistance, P.I. Makushin, Sources of Financing, F.F. Pavlenkov, Private Capital, Publishers, Book Sellers, Trusteeship on People's Sobriety.

Citation: Timofeeva Y.V. Sources of Financing the Libraries established with the assistance of the Society for Promotion of Rural Free Libraries-Reading Rooms in the Tomsk Province (1901-1919), Bibliotekovedenie [Library and Information Science (Russia)], 2018, vol. 67, no. 1, pp. 91-101. DOI: 10.25281/0869608X-2018-67-1-91-101.

\section{References}

1. Kurmaev M.V. Knizhnaya kul'tura Srednego Povolzh'ya kontsa XVIII - nachala XX vv. (na materialakh Penzenskoi, Simbirskoi i Samarskoi gubernii) [The Book Culture of the Middle Volga Region of the End of the 18th - Beginning of the 20th Centuries (On the Materials of the Penza, Simbirsk and Samara Provinces)], Doct, hist. sci. diss. abstr. Samara, 2010, 50 p.

2. Panchenko A.M. Istoriya voennykh bibliotek $v$ kontekste razvitiya bibliotechnogo dela Rossii (1802-1917 gg.) [The History of Military Libraries in the Context of Librarianship Development in Russia (18021917)], Doct. hist. sci. diss. abstr. Novosibirsk, 2017, $57 \mathrm{p}$.

3. Panchenko A.M. The Financing of the Russian Army Officer's Libraries in the Second Half of the 19th Beginning of the 20th Century, $V$ Sibiri rozhdennoe: $k$ 40-letiyu Novosibirskogo vysshego voennogo komandnogo uchilishcha (1967-2007): materialy nauch. konf. (Novosibirsk, 27 aprelya 2007 g.) [Proceedings of the Sci. Conf. "Born in Siberia: To the 40th Anniversary of the Novosibirsk Higher Military Command School (1967-2007)" (Novosibirsk, 2007, April 27)]. Novosibirsk, 2007, pp. 115-126 (in Russ.).

4. Khronika [Chronicle], Bibliotekar' [Librarian], 1912, issues III-IV, pp. 261-277. 
5. Pronina M.G. The Society for Promotion of Rural Free Libraries-Reading Rooms in the Tomsk Province, Knizhnoe delo Sibiri i Dal'nego Vostoka v XIX$X X v v$. [The Book Publishing in Siberia and the Far East in the 19th-20th Centuries]. Novosibirsk, GPNTB SO RAN Publ., 1986, pp. 39-50 (in Russ.).

6. Kartashova T.P. Makushin Libraries and the Local Print Production Promotion in Tomsk Province in the Early XX Century, Kniga: Sibir' - Evraziya: $t r$. I Mezhdunar. nauch. kongr.: $v 3 t$. [Proceedings of the 1st International Scientific Congress "Book: Siberia Eurasia": in 3 volumes]. Novosibirsk, GPNTBSO RAN Publ., 2016, vol. 2, pp. 211-219 (in Russ.).

7. Timofeeva Yu.V.Knizhnaya kul'tura sel'skogonaseleniya Zapadnoi Sibiri (konets XIX - nachalo XX v.): monografiya [Book Culture of the Rural Population of Western Siberia (The End of the 19th - Beginning of the 20th Century): monograph]. Novosibirsk, Tsentr Razvitiya Nauchnogo Sotrudnichestva Publ., 2012, 193 p.

8. Timofeeva Yu.V. What a Report Has Talked About, or the Potential of a Single Document, Istoriya i istoriografiya Rossii i Sibiri v issledovatel'skom i obrazovatel'nom kontekstakh: materialy Vseros. nauch.-prakt. konf. (Novosibirsk, 15-16 aprelya 2014 g.) [Proceedings of the All-Russian Sci.-Pract. Conf. "The History and Historiography of Russia and Siberia in the Research and Educational Contexts" (Novosibirsk, 2014, April 15-16)]. Novosibirsk, Novosibirskii Gosudarstvennyi Pedagogicheskii Universitet Publ., 2014, pp. 103-108 (in Russ.).

9. Menshchikova S.P. At the Origins of Public Education in Siberia, Vestnik Bibliotechnoi Assamblei Evrazii [Herald of the Library Assembly of Eurasia], 2015, no. 3, pp. 85-87 (in Russ.).

10. Timofeeva Yu.V. Pyotr Ivanovich Makushin and the Promotion of Public Libraries in the Tomsk Province in the Early 20th Century, Vestnik Bibliotechnoi Assamblei Evrazii [Herald of the Library Assembly of Eurasia], 2015, no. 3, pp. 88-91 (in Russ.).

11. Otchet Soveta Obshchestva sodeistviya ustroistvu sel'skikh besplatnykh bibliotek-chitalen $v$ Tomskoi gubernii za 1908-1909 gg. [The Report of the Council of the Society for Promotion of Rural Free Libraries and Reading Rooms in the Tomsk Province for 1908-1909]. Tomsk, Sibirskogo Tovarishchestva Pechatnogo Dela Publ., 1910, 30 p.
12. Kratkii ocherk vozniknoveniya i deyatel'nosti $\mathrm{Ob}$ shchestva sodeistviya ustroistvu sel'skikh besplatnykh bibliotek-chitalen $v$ Tomskoi gub. za vremya ego sushchestvovaniya i otchet Soveta Obshchestva za 1910-1912 gg. [A Brief Essay of the Origin and Activities of the Society for Promotion of Rural Free Libraries and Reading Rooms in the Tomsk Province for the Period of its Existence and the Report of the Council of the Society for 1910-1912]. Tomsk, Doma Trudolyubiya Publ., 1912, 45 p.

13. Otchet Soveta Obshchestva sodeistviya ustroistvu sel'skikh besplatnykh bibliotek-chitalen $v$ Tomskoi gubernii za 1904-1907 gg. [The Report of the Council of the Society for Promotion of Rural Free Libraries and Reading Rooms in the Tomsk Province for 1904-1907]. Tomsk, Sibirskogo Tovarishchestva Pechatnogo Dela Publ., 1908, 49 p.

14. Otchet Soveta Obshchestva sodeistviya ustroistvu sel'skikh besplatnykh bibliotek-chitalen $v$ Tomskoi gubernii za 1901-1903 gg. [The Report of the Council of the Society for Promotion of Rural Free Libraries and Reading Rooms in the Tomsk Province for 19011903]. Tomsk, P.I. Makushina Publ., 1904, 30 p.

15. Timofeeva Yu.V. Libraries of the Society for Promotion of Rural Free Libraries-Reading Rooms in the Tomsk Province (1901-1919), Bibliotekove denie [Library and Information Science (Russia)], 2017, vol. 66 , no. 4 , pp. $443-450$ (in Russ.). DOI: 10.25281/0869-608Kh-2017-66-4-443-450.

16. Uchastie knigoprodavtsev i izdatelei $v$ uchrezhdenii narodnykh bibliotek-chitalen $v$ Tomskoi gubernii [Booksellers and Publishers' Participation in the Establishment of Public Libraries-Reading Rooms in the Tomsk Province]. Tomsk, Sibirskogo Tovarishchestva Pechatnogo Dela Publ., 1916, 7 p.

17. Timofeeva Yu.V. The First Two Libraries of the Society for Promotion of Rural Free Libraries-Reading Rooms in the Tomsk Province (The First Decade of the 20th Century), Bibliotekovedenie [Library and Information Science (Russia)], 2017, vol. 66, no. 2, pp. 202-208 (in Russ.). DOI: 10.25281/0869-608Kh2017-66-2-202-208.

18. Makushin P.I. From the "Autobiography”, Sibirskaya starina [Siberian Antiquity], 2002, no. 19, pp. 35-41 (in Russ.). 